\title{
Titanium dioxide nanoparticles enhance thrombosis through triggering the phosphatidylserine exposure and procoagulant activation of red blood cells
}

Yiying Bian ${ }^{1 *}$, Han-Young Chung ${ }^{2}$, Ok-Nam Bae ${ }^{3}$ Kyung-Min Lim ${ }^{4}$, Jin-Ho Chung ${ }^{5^{*}}$ (D) and Jingbo Pi $1^{1 *}$

\begin{abstract}
Background: Expanding biomedical application of anatase titanium dioxide $\left(\mathrm{TiO}_{2}\right)$ nanoparticles (NPs) is raising the public concern on its potential health hazards. Here, we demonstrated that $\mathrm{TiO}_{2} \mathrm{NPs}$ can increase phosphatidylserine (PS) exposure and procoagulant activity of red blood cells (RBCs), which may contribute to thrombosis.

Results: We conducted in vitro studies using RBCs freshly isolated from healthy male volunteers. $\mathrm{TiO}_{2} \mathrm{NPs}$ exposure $(\leqq 25 \mu \mathrm{g} / \mathrm{mL}$ ) induced PS exposure and microvesicles (MV) generation accompanied by morphological changes of RBCs. While ROS generation was not observed following the exposure to $\mathrm{TiO}_{2} \mathrm{NPs}$, intracellular calcium increased and caspase-3 was activated, which up-regulated scramblase activity, leading to PS exposure. RBCs exposed to $\mathrm{TiO}_{2}$ NPs could increase procoagulant activity as measured by accelerated thrombin generation, and enhancement of RBC-endothelial cells adhesion and RBC-RBC aggregation. Confirming the procoagulant activation of RBC in vitro, exposure to $\mathrm{TiO}_{2} \mathrm{NPs}$ (2 $\mathrm{mg} / \mathrm{kg}$ intravenously injection) in rats increased thrombus formation in the venous thrombosis model.
\end{abstract}

Conclusion: Collectively, these results suggest that anatase $\mathrm{TiO}_{2} \mathrm{NPs}$ may harbor prothrombotic risks by promoting the procoagulant activity of RBCs, which needs attention for its biomedical application.

Keywords: Titanium dioxide nanoparticles $\left(\mathrm{TiO}_{2} \mathrm{NPS}\right)$, Phosphatidylserine (PS) exposure, Procoagulant activity, Thrombosis, Red blood cells (RBCs)

\section{Background}

In addition to the wide use in sunscreens, titanium dioxide nanoparticles $\left(\mathrm{TiO}_{2} \mathrm{NPs}\right)$ are receiving an increasing attention for biomedical applications like cell imaging, biological analysis, drug delivery and photodynamic therapy owing to their excellent and unique photocatalytic

\footnotetext{
* Correspondence: byy19900719@snu.ac.kr; yybian@cmu.edu.cn; jhc302@snu.ac.kr; jbpi@cmu.edu.cn

'School of Public Health, China Medical University, Shenyang 110122,

People's Republic of China

${ }^{5}$ College of Pharmacy, Seoul National University, Seoul 151-742, South Korea Full list of author information is available at the end of the article
}

properties, and good biocompatibility [1-5]. Due to their wide and heavy uses in human life, concern of health hazard of $\mathrm{TiO}_{2}$ NPs is escalating and many researches have illuminated that $\mathrm{TiO}_{2}$ NPs can induce various pathological alterations in liver, spleen, kidneys and brain [6]. Meanwhile, the toxicity of $\mathrm{TiO}_{2} \mathrm{NPs}$ on blood cells, the primary target cells of intravenously given substances, remains relatively unillustrated.

Indeed, previous studies demonstrated that some nanoparticles can inflict cytotoxicity and genotoxicity on lymphocyte cells $[7,8]$ and activate platelets, resulting in

C C The Author(s). 2021 Open Access This article is licensed under a Creative Commons Attribution 4.0 International License, which permits use, sharing, adaptation, distribution and reproduction in any medium or format, as long as you give appropriate credit to the original author(s) and the source, provide a link to the Creative Commons licence, and indicate if changes were made. The images or other third party material in this article are included in the article's Creative Commons licence, unless indicated otherwise in a credit line to the material. If material is not included in the article's Creative Commons licence and your intended use is not permitted by statutory regulation or exceeds the permitted use, you will need to obtain permission directly from the copyright holder. To view a copy of this licence, visit http://creativecommons.org/licenses/by/4.0/ The Creative Commons Public Domain Dedication waiver (http://creativecommons.org/publicdomain/zero/1.0/) applies to the data made available in this article, unless otherwise stated in a credit line to the data. 
thrombosis $[9,10]$, reflecting that blood cells can be an important target of toxicity for nanoparticles. RBCs are also reported as a target of nanoparticles but the effects are mainly limited to hemolysis, morphological alterations or RBC aggregation [11-13]. Recently, an active role of RBCs in the development of thrombotic diseases has been demonstrated. Participating in thrombosis, RBCs accelerate the cascade of coagulation and the formation of blood clotting through externalization of phosphatidylserine (PS) on the outer membrane providing a procoagulant sites and faciliating thrombin generation [14]. This process is called as the procoagulant activity of RBCs, which is triggered by the perturbation of membrane phospholipid translocases; scramblase and flippase. Perturbation of membrane phospholipid translocases are caused by upstream events of intracelluar calcium increase, caspase activation, ROS production as well as ATP- and thiol-depletion [15-21].

Our previous study firstly demonstrated that the procoagulant activity of RBCs can be induced by silver nanoparticles, enhancing thrombosis [22], reflecting the role of RBCs in prothrombotic effects of nanoparticles. Previous studies showed that $\mathrm{TiO}_{2}$ NPs can induce hemolysis, morphological observation and a possible interaction with RBCs via penetration [7, 23, 24], implying their potental effects on RBCs with respect to procoagulant activity and thrombosis [23]. However, previous studies have not further extended into the investigation of the possible effects of $\mathrm{TiO}_{2} \mathrm{NPs}$ on the development of procoagulant activity of $\mathrm{RBCs}$ and thrombosis.

Here, we examined whether $\mathrm{TiO}_{2}$ NPs can affect PS exposure and procoagulant activity of RBCs. In addition, we clarified the underlying mechanism and investigated the biological significances by evaluating the procoagulant activity of RBCs, RBC adhesion to endothelial cells and RBC aggregates. Importanly, the signficance of these findings with respect to human thrombosis were further substantiated by in vivo thrombosis using a rat venous thrombosis model.

\section{Results}

\section{Characterization of $\mathrm{TiO}_{2} \mathrm{NPs}$ and TEM analysis of $\mathrm{TiO}_{2}$} NPs-exposed RBCs

The size distribution of $\mathrm{TiO}_{2}$ NPs was characterized with scanning electron microscopy (SEM) and dynamic light scattering (DLS). SEM observation showed that the majority of $\mathrm{TiO}_{2} \mathrm{NPs}$ was at the size ranges of 20 to 45 $\mathrm{nm}$ with the average size of $33.2 \mathrm{~nm}$ as calculated with sampled one hundred particles (Fig. 1a). DLS data showed the peak and average size by intensity in Ringer's solution (with 10\% FBS) was $68.1 \mathrm{~nm}$ and $72.32 \mathrm{~nm}$, respectively, and in saline (with 10\% FBS), was $122.4 \mathrm{~nm}$ and $120.4 \mathrm{~nm}$, respectively (Fig. 1b). In addition, the zeta potential of $\mathrm{TiO}_{2}$ NPs was $-8.70 \mathrm{mV}$ in Ringer's solution and $-10.58 \mathrm{mV}$ in saline ( $\mathrm{pH}$ 7.4). The physiochemical properties of $\mathrm{TiO} 2 \mathrm{NPs}$ were summarized in Supplemental Table S1. Next, we could also observe that $\mathrm{TiO}_{2}$ NPs penetrates through $\mathrm{RBCs}$ membranes and enter into RBCs using transmission electron microscopy (TEM) (Fig. 1c), which matched well the previous findings provided by $\mathrm{Li}$, et al., and Rothen-Rutishauser, et al., [23, 24], indicating that $\mathrm{TiO}_{2}$ NPs exposure may produce significant biological or toxic effects on RBCs.

\section{Effects of $\mathrm{TiO}_{2} \mathrm{NPs}$ on human isolated RBCs in vitro}

Firstly, we determined the hemolytic reactions of $\mathrm{TiO}_{2}$ NPs on human isolated RBCs and found that $50 \mu \mathrm{g} / \mathrm{mL}$ of $\mathrm{TiO}_{2} \mathrm{NPs}$ caused a significant lysis while $0 \sim 25 \mu \mathrm{g} /$ $\mathrm{mL}$ did not, where we continued our investigation in the following study (Fig. 2a). PS exposure and MV generation, key indicators of procoagulant activity of RBCs participating in thrombosis, were examined using flow cytometry [25]. Figure $2 \mathrm{~b}$ showed that 10 to $25 \mu \mathrm{g} / \mathrm{mL}$ of $\mathrm{TiO}_{2}$ NPs treatment for $24 \mathrm{~h}$ significantly elicited PS exposure. The generation of PS-bearing MV (Fig. 2c) from $\mathrm{TiO}_{2}$ NPs-treated RBCs also increased in a concentration-dependent fashion. SEM observation showed the appearance of spiny cells, called echinocytes, in $\mathrm{TiO}_{2}$ NPs-treated groups (Fig. 2d). These findings reflect a well-known relationship between loss of phospholipid asymmetry and morphological changes [26]. Plasma coagulation, one of key events contributing to thrombosis, was estimated by measuring the prothrombin time (PT) and the activated partial thromboplastin time (aPTT), but no effects were induced by $\mathrm{TiO}_{2} \mathrm{NPs}$ up to a level of 10 folds more than that exposed to RBCs (Fig. 2e), indicating the specificity in the effects of $\mathrm{TiO}_{2} \mathrm{NPs}$ to RBCs. Indeed, compared to anatase $\mathrm{TiO}_{2} \mathrm{NPs}$, we futher determined hemolysis and PS exposure of rutile type and anatase/rutile mixture (Supplemental Figure 1), showing the toxicity was mixture $>$ anatase $>$ rutile.

\section{Effects of $\mathrm{TiO}_{2}$ NPs on phospholipid translocase, intracellular calcium level $\left(\left[\mathrm{Ca}^{2+}\right]_{\mathrm{i}}\right)$, and caspase activity in RBCs}

PS externalization is resulting from the disruption of phospholipid asymmetry, which is controlled by a balance of phospholipid translocases activity; scramblase and flippase [19]. After $24 \mathrm{~h}$ incubation with $\mathrm{TiO}_{2} \mathrm{NPs}$, scramblase activity was significantly upregulated in a concentration-dependent manner as evidenced by increased C6-NBD-PC translocation (Fig. 3a, left). On the contrary, $\mathrm{TiO}_{2}$ NPs exposure did not affect flippase activity as examined by absence of embedded C6-NBD-PS translocation (Fig. 3a, right), reflecting loss of phospholipid asymmetry leading to PS exposure induced by $\mathrm{TiO}_{2}$ 

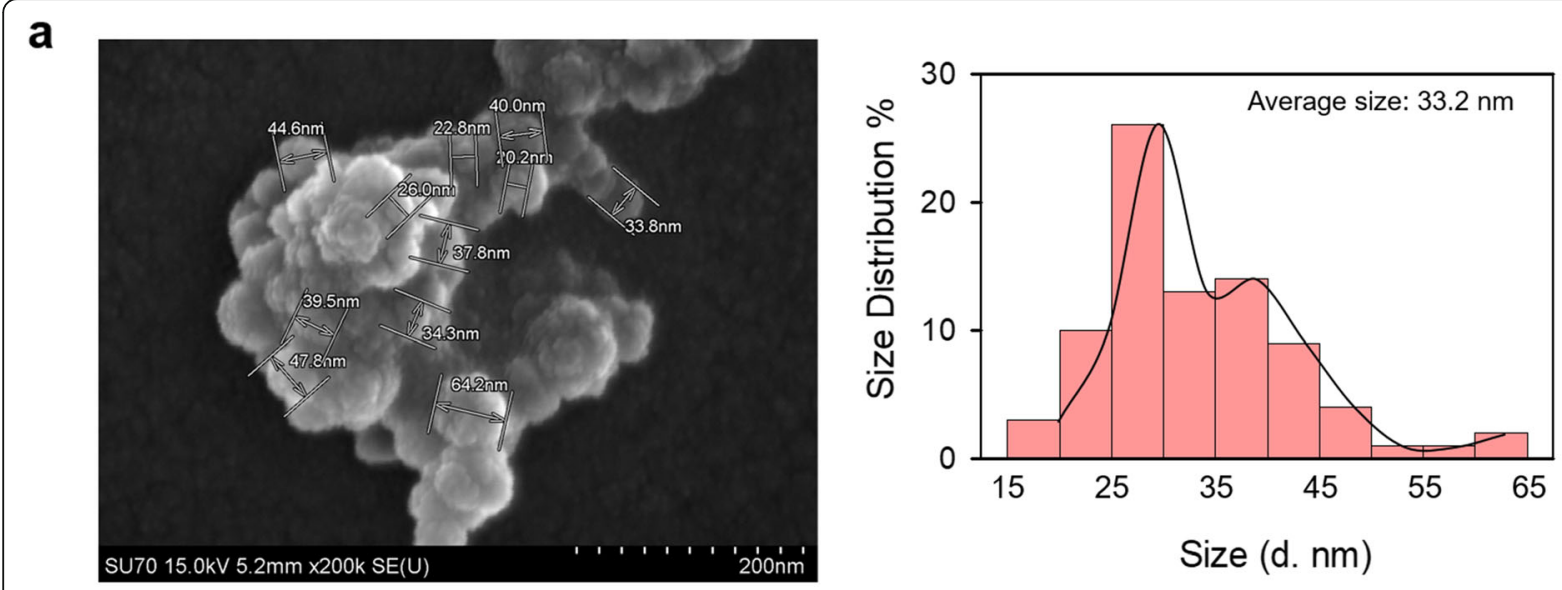

b

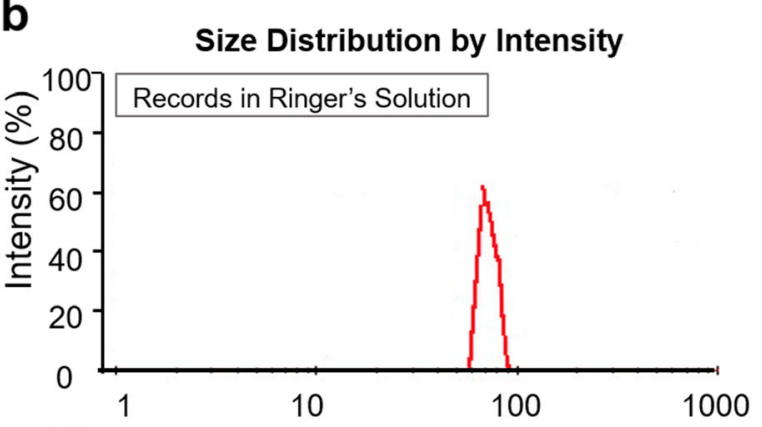

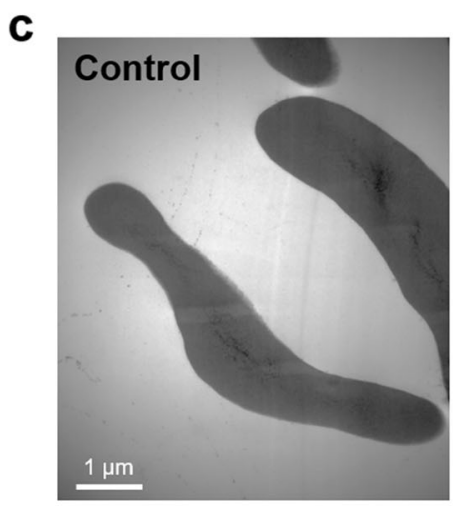

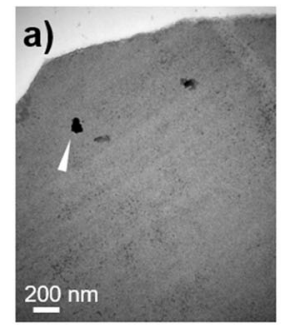

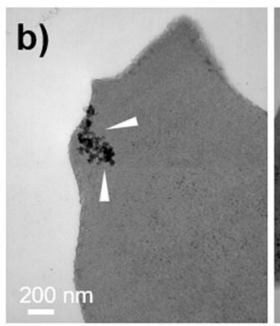

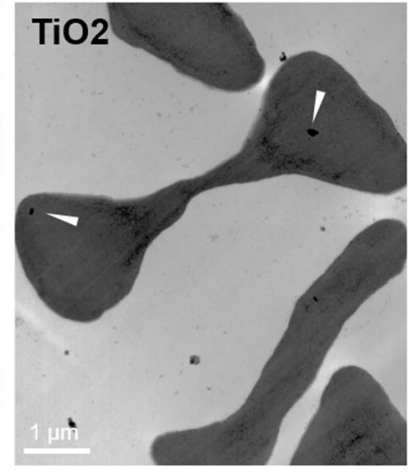

c)

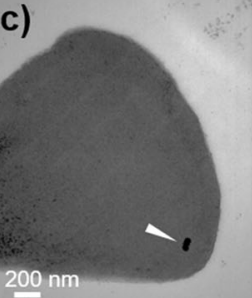

Fig. 1 Characterization of $\mathrm{TiO}_{2}$ NPs and transmission electron microscope (TEM) observation of cellular uptake. (a) The size distribution histogram generated using SEM images showed $\mathrm{TiO}_{2}$ NPs of size between 15 and $65 \mathrm{~nm}$ with an average of $33.2 \mathrm{~nm}$. Value are calculated from randomly measuring more than 100 particles of $\mathrm{TiO}_{2}$ NPs observed by SEM. (b) Particle size distribution of $\mathrm{TiO}_{2} \mathrm{NPs}$ in Ringer's solution used in vitro system and in saline used for intravenous injection showed particles of diameter with a peak of distribution at $68.1 \mathrm{~nm}$ and $122.4 \mathrm{~nm}$, respectively (with $10 \%$ FBS in it). The results also indicated the presence of $\mathrm{TiO}_{2}$ NPs agglomerates both in Ringer's solution and in saline. (c) Control (distilled water) and $\mathrm{TiO}_{2} \mathrm{NPs}$-treated RBCs were observed using TEM after $24 \mathrm{~h}$ treatment. The white arrowheads indicated $\mathrm{TiO}_{2} \mathrm{NPs}_{\text {might }}$ go through RBCs membranes and uptake by RBCs. Black scale bar: $2 \mu \mathrm{M}$. * represents significant differences from control group $(p<0.05)$

was mainly attributable to the increased scramblase activity.

Scramblase activity was known to be increased by ROS [27, 28], intracellular calcium elevation [17] [29], and caspase-3 activation [30]. Compared to the positive control (Pb-treated RBCs) and negative control, no ROS generation was observed in RBCs following the treatment of $\mathrm{TiO}_{2}$ NPs (Fig. 3b). On the contrary, $25 \mu \mathrm{g} / \mathrm{mL}$ of $\mathrm{TiO}_{2}$ NPs resulted in increased $\left[\mathrm{Ca}^{2+}\right]_{\mathrm{i}}$ in RBCs (Fig. 3c). As well as increased $\left[\mathrm{Ca}^{2+}\right]_{i}$, caspase-3 was significantly activated by $\mathrm{TiO}_{2}$ NPs exposure (Fig. 3d). The roles of increased $\left[\mathrm{Ca}^{2+}\right]_{\mathrm{i}}$ and activated caspase 3 in $\mathrm{TiO}_{2} \mathrm{NP}$-induced PS exposure in RBCs were further confirmed through pretreatment of their inhibitors, EGTA and Z-VAD-FMK, which succeeded to attenuate the PS exposure induced by $\mathrm{TiO}_{2}$ NPs treatment (Fig. 3e).

\section{Procoagulant activity of $\mathrm{TiO}_{2}$ NPs-exposed RBCs}

Procoagulant activity of RBCs results in accelerated thrombin generation, a key step for blood coagulation 


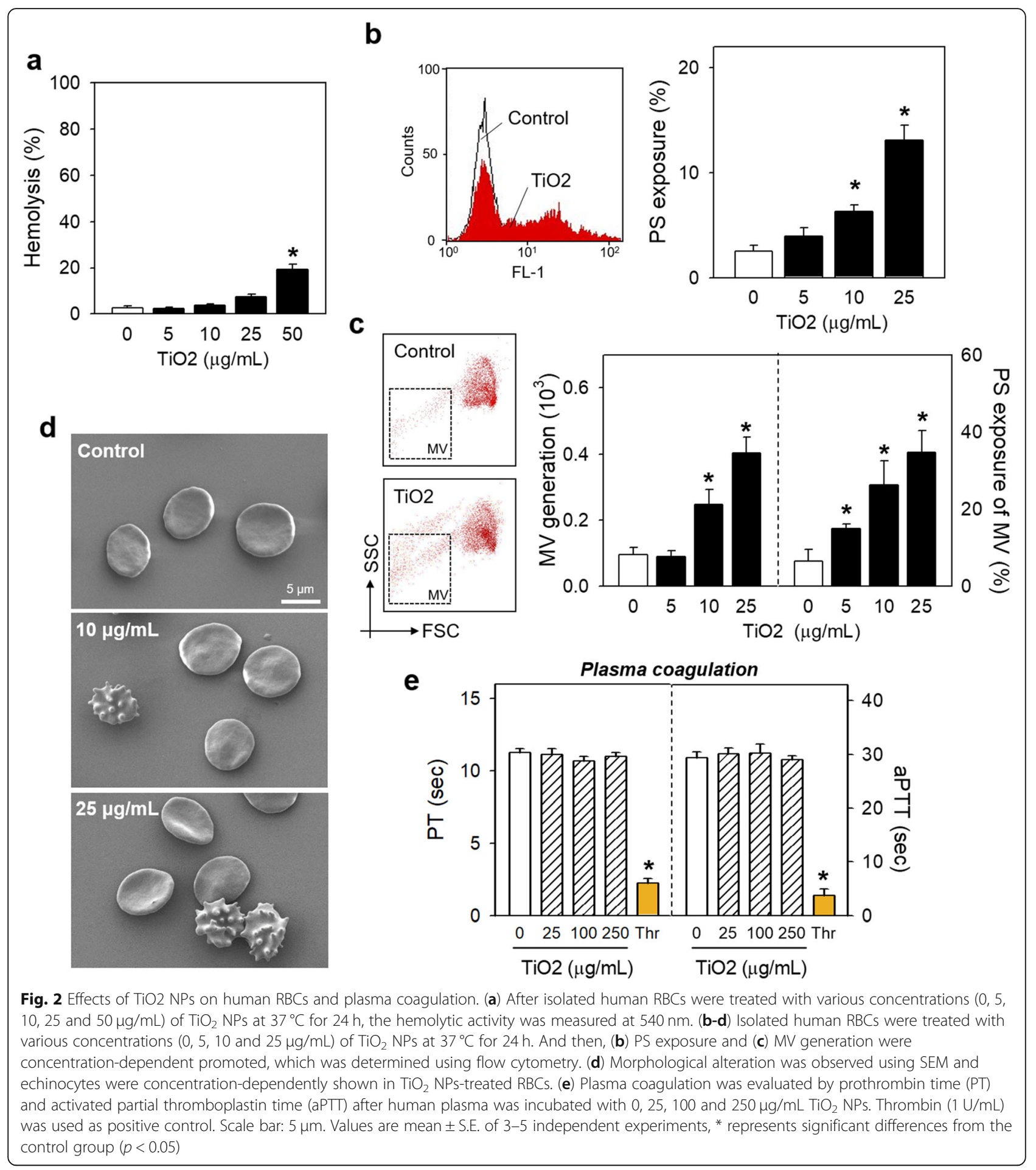

cascade, and the adhesion of RBCs to vascular wall, which could ultimately promote thrombosis [31]. Firstly, prothrombinase assay was performed to detect thrombin generated by $\mathrm{TiO}_{2}$ NPs-exposed RBCs. As a result, a concentration-dependent increase in thrombin generation was induced by $\mathrm{TiO}_{2}$ NPs as shown in Fig. 4a. It was well-matched with PS exposure and MV generation shown in Fig. 2b and c. Also, $\mathrm{TiO}_{2}$ NPs-exposed RBCs were more-adhesive to ECs with a concentrationdependent trend as observed by fluorescence microscopy shown in Fig. 4b. Of note, some red aggregates also appeared in $\mathrm{TiO}_{2}$ NPs-treated groups, suggestive of RBCs 

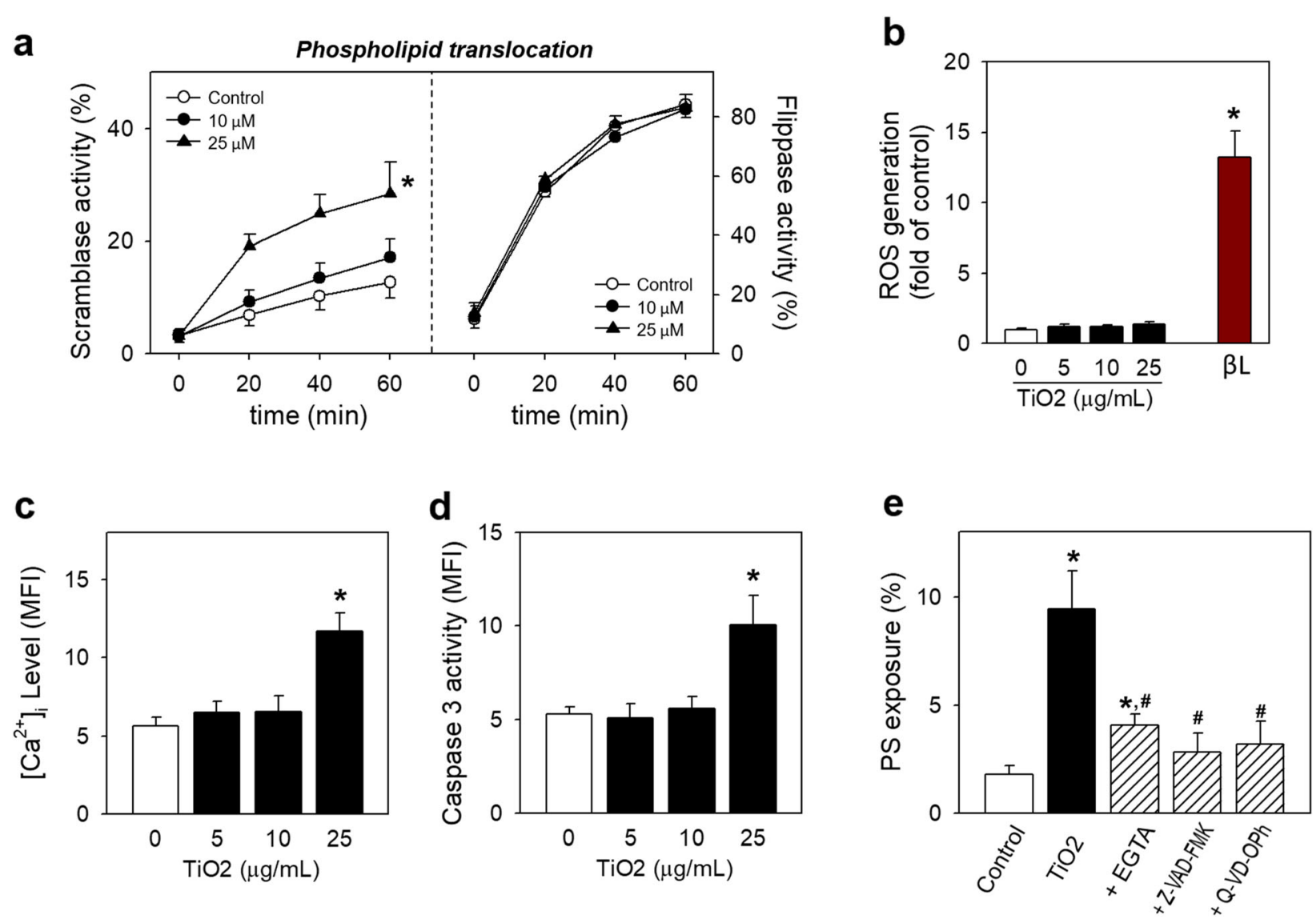

Fig. 3 Intracellular events underlying PS exposure in RBCs induced by $\mathrm{TiO}_{2} \mathrm{NPs}$. Isolated human $\mathrm{RBCs}$ were treated with various concentrations $(0$, 5,10 and $25 \mu \mathrm{g} / \mathrm{mL}$ ) of $\mathrm{TiO}_{2} \mathrm{NPs}$ at $37^{\circ} \mathrm{C}$ for $24 \mathrm{~h}$. Next, phospholipid translocation was shown by (a) concentration-dependently increased scramblase activity and (b) no changes of flippase activity. (b) ROS generation was determined through preloading $5 \mu \mathrm{M} C M-\mathrm{H}_{2} \mathrm{DCF}-\mathrm{DA}$ for 30 min, and beta-lapachone was used as positive control. (c) Intracellular calcium, $\left[\mathrm{Ca}^{2+}\right]_{\text {i, }}$ was examined by preloading $3 \mu \mathrm{M}$ fluo-4 AM for $1 \mathrm{~h}$. (d) Caspase 3 activity was increased as measured shown in Method. (e) Inhibition of PS exposure was performed by preloading various inhibitors, a calcium chelating agent (5 mM EGTA) or caspase inhibitors (Z-VAD-FMK and Q-VD-Oph) for $3 \mathrm{~h}$ prior to exposure to TiO2 NPs for $24 \mathrm{~h}$. Values are mean \pm S.E. of 3-5 independent experiments, * represents significant differences from the control group $(p<0.05)$

aggregation after $\mathrm{TiO}_{2} \mathrm{NPs}$ exposure. Indeed, $\mathrm{TiO}_{2} \mathrm{NPs}-$ exposed RBCs became more prone to aggregate in a concentration-dependent fashion (Fig. 4c).

\section{Prothrombotic effects of $\mathrm{TiO}_{2}$ NPs exposure in vivo}

Prior to in vivo assessment of $\mathrm{TiO}_{2}$ NPs in rats, a bridge study was performed using freshly isolated rats RBCs to confirm the procoagulant effects of $\mathrm{TiO}_{2} \mathrm{NPs}$ on rat RBCs. Consistently with human RBCs, rat RBCs exposed to $\mathrm{TiO}_{2} \mathrm{NPs}$ showed a concentration-dependent increase in PS exposure and thrombin generation (Fig. 5a) (Scheme 1). Next we examined whether $\mathrm{TiO}_{2} \mathrm{NPs}$ exposure could elicit thrombosis using venous thrombosis rat model $1 \mathrm{~h}$ after $\mathrm{TiO}_{2}$ NPs were intravenously injected $(0,2,10,25 \mathrm{mg} / \mathrm{kg})$ to rats. On average, rats have around $64 \mathrm{ml}$ of blood per $\mathrm{kg}$ of bodyweight [32]. And when we injected $2 \mathrm{mg} / \mathrm{kg}$ of $\mathrm{TiO}_{2} \mathrm{NPs}$, there will be around $30 \mu \mathrm{g} / \mathrm{mL}$ in rat blood, which matched well with in vitro concentrations exposed to isolated blood. As a result, thrombus formation was significantly increased by $\mathrm{TiO}_{2}$ NPs in a dose-related fashion (Fig. 5b), confirming the thrombotic risks of $\mathrm{TiO}_{2}$ NPs.

\section{Discussion}

In this study, we demonstrated that titanium dioxide nanoparticles $\left(\mathrm{TiO}_{2} \mathrm{NPs}\right)$ could initiate phosphatidylserine (PS) exposure and promote procoagulant activity in isolated human red blood cells (RBCs) and rat RBCs. Here, intracellular calcium increase and caspase 3 activity up-regulated scramblase activity leading to loss of phospholipid asymmetry and PS exposure in $\mathrm{TiO}_{2}$ NPstreated RBCs. Furthermore, $\mathrm{TiO}_{2}$ NPs led to accelerated thrombin generation, RBC-EC adhesion as well as RBC aggregation, and more importantly, could increase thrombus formation in rats in vivo supporting the relevance of our findings to real in vivo states. 


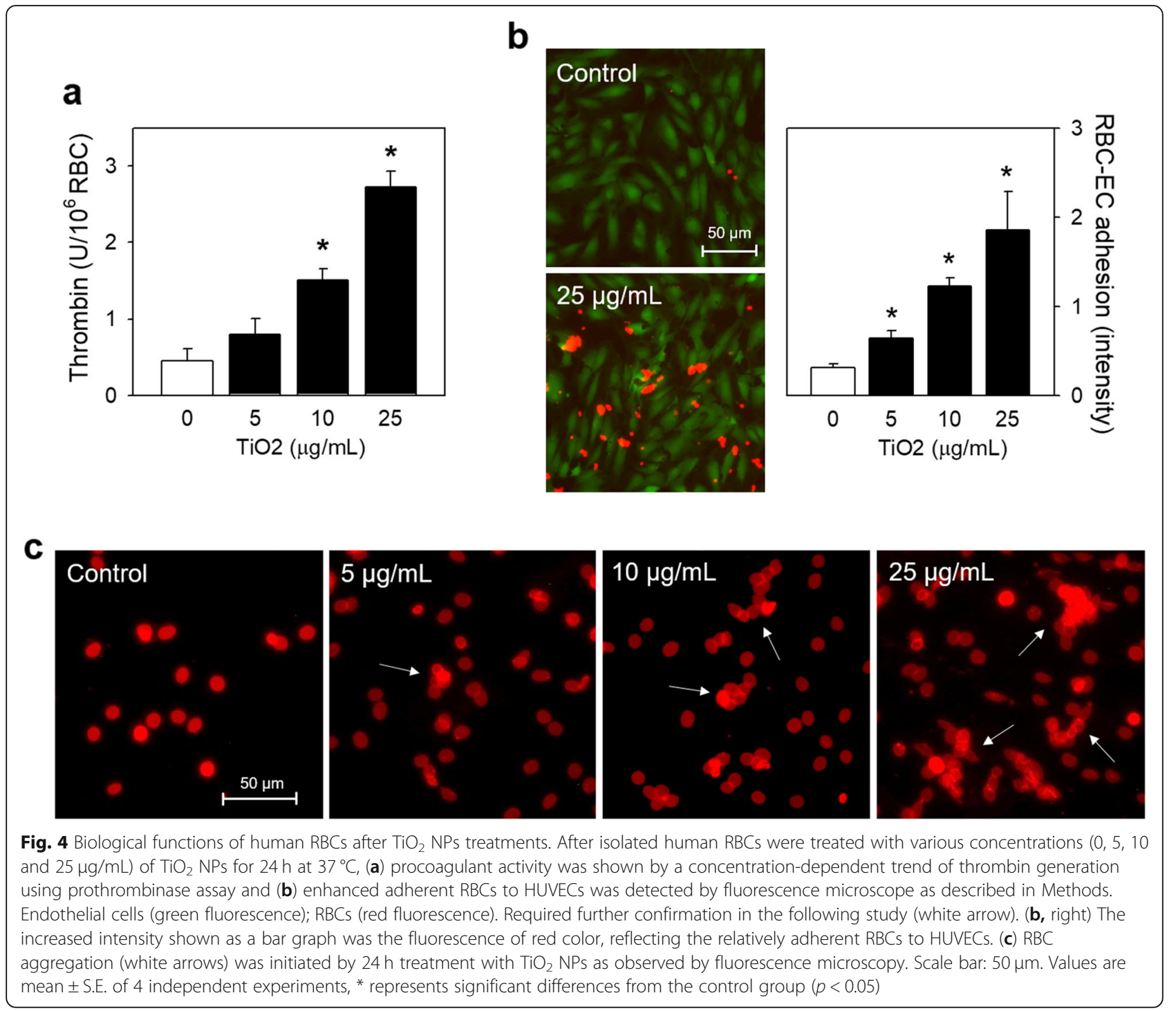

Previous studies showed that $\mathrm{TiO}_{2}$ NPs can induce toxicity in various cells and tissues in vitro, such as lymphocytes, platelets and liver tissues, but their pathophysiological implications remained unexplored $[6,7,10,33,34]$. In RBCs, hemolysis is repeatedly observed as $\mathrm{TiO}_{2}$ NP-induced toxicity in several studies $[7,24,35]$, but its pathophysiological significance is poorly understood. Recently, $\mathrm{Li}$ et al. have observed that $\mathrm{TiO}_{2} \mathrm{NPs}$ adhere to $\mathrm{RBC}$ membranes and induce the morphological alterations [24]. In this study, we demonstrated that the $\mathrm{TiO}_{2}$ NPs can induce procoagulant activation of $\mathrm{RBCs}$ both in vitro and in vivo systems. We also elucidated its underlying mechanisms and explored its further biological significance in terms of thrombosis, providing with a comprehensive and convincing evidence on the prothrombotic effects of $\mathrm{TiO}_{2}$ via the procoagulant activity of RBCs.

$\mathrm{TiO}_{2}$ NPs are applied via intravenous administration for their medical uses [36], raising the necessity of the careful and rigorous safety assessment of $\mathrm{TiO}_{2}$ application in vivo. An earlier study investigated $\mathrm{TiO}_{2}$ toxicity in mice using an extremely high dosage $(0,140,300$, 645 , or $1387 \mathrm{mg} / \mathrm{kg}$ ), found diverse degrees of dysfunction in the brain, lung, spleen, liver and kidneys [37]. Another study demonstrated that i.v. injection of $5 \mathrm{mg} /$ $\mathrm{kg}$ of $\mathrm{TiO}_{2}$ to rats were without detectable toxicity, and suggested a safe level of $\mathrm{TiO}_{2}$ up to $5 \mathrm{mg} / \mathrm{kg}$ [38]. But these studies appear to focus the general toxicology, leaving subtle pathophysiological effects unaddressed. Our study showed that $\mathrm{TiO}_{2}$-injection at $2 \mathrm{mg} / \mathrm{kg}$ i.v can provoke thrombosis, suggesting that careful attention 
a

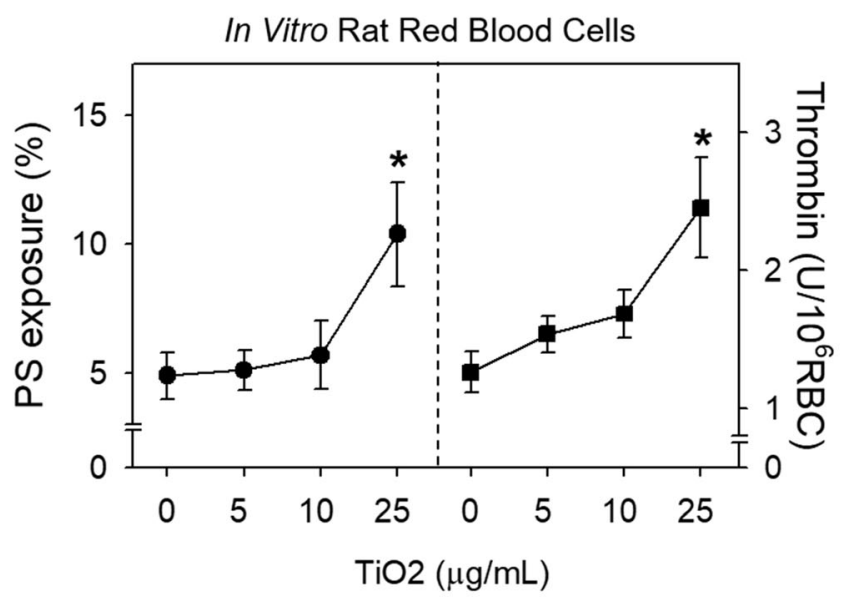

b

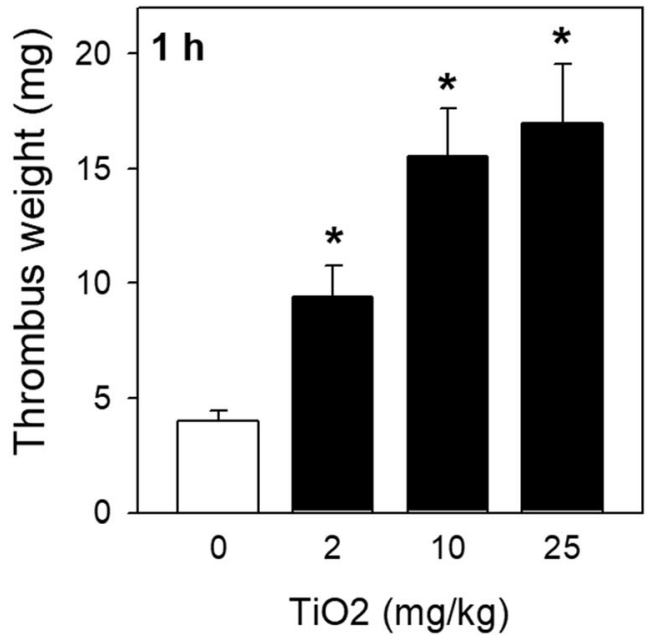

Fig. 5 Thrombotic effects of $\mathrm{TiO}_{2}$ NPs exposure after intravenously injection to rat. (a) Blood was freshly collected from 8-week-old SD rats, and isolated rat RBCs were further incubated with various concentrations $\left(0,5,10\right.$ and $25 \mu \mathrm{g} / \mathrm{mL}$ ) of $\mathrm{TiO}_{2} \mathrm{NPs}$. (a, left) PS exposure as well as (a, right) thrombin generation were evaluated. (b) In a venous animal model, various doses of $\mathrm{TiO}_{2} \mathrm{NPs}_{\text {sas }}$ intravenously injected to rats, and $1 \mathrm{~h}$ later, thrombus formation was assessed. Values are mean \pm S.E. of $4-5$ independent experiments, ${ }^{*}$ represents significant differences from the control group $(p<0.05)$

shall be paid for pathophysiological effects of $\mathrm{TiO}_{2} \mathrm{NPs}$ as well to ensure the safety.

In addition, bio-distribution after i.v. injections of $\mathrm{TiO}_{2}$ NPs in rats investigated in several studies revealed that a majority of $\mathrm{TiO}_{2} \mathrm{NPs}$ distributes in blood followed by spleen, liver and lung [38-40]. A recent study showed that after i.v. administration of $0.95 \mathrm{mg} / \mathrm{kg} \mathrm{TiO}_{2} \mathrm{NPs}$ in rats, the blood level of $420 \mathrm{ng} / \mathrm{mL}$ was observed at 5 min, which is similar to the range employed in our studies in vitro and in vivo. Moreover, the half-life of $\mathrm{TiO}_{2}$ NPs was determined to be very long ranging up to 12.56 days in rat after giving i.v injection [39], suggesting that stronger prothrombotic effects of $\mathrm{TiO}_{2} \mathrm{NPs}$ could be anticipated, although further studies are necessary to confirm it.

Oxidative stress accompanied by decreased glutathione and overproduced ROS has been frequently involved in the toxicity of $\mathrm{TiO}_{2} \mathrm{NPs}$ exposure $[41,42]$. In contrast, we found no obvious production of ROS in $\mathrm{TiO}_{2} \mathrm{NPs}-$ treated RBCs at any concentrations, which is in line with a previous finding that intracellular glutathione levels in blood, lung and liver cells were not affected by $\mathrm{TiO}_{2}$ NPs [43]. Instead, we newly found that intracellular calcium and caspase- 3 activation are elicited after $\mathrm{TiO}_{2}$ NPs exposure, revealing new molecular targets for the toxicity of $\mathrm{TiO}_{2}$ NPs. We suggest that studies are necessary to identify the role of intracellular calcium increase and caspase-3 activation in other pathological effects of $\mathrm{TiO}_{2}$ NPs in the near future.
Various $\mathrm{TiO} 2$ NPs possess distinct physicochemical properties, such as particle sizes, crystalline forms (anatase or rutile phase), surface modification (surface charge and coating), and protein corona formation, each of which would be expected to substantially affect their biological properties. It is well established that the anatase form of $\mathrm{TiO} 2$ is more bioactive than rutile type which, together with smaller size, can result in greater toxicity $[6,44]$. Also, the surface functionalization of NPs with negatively charged groups could alleviate the erythrocyte aggregating effects of these NPs [45], which could be attributable to the formation of a complex system on the NP surface induced by surface modification. Exemplifying this, a previous study showed that BSAcoated gold NPs induce significantly lower hemolysis [46]. NP-protein corona complex formation could also affect the biological properties of NPs [47]. A previous study demonstrated that the formation of plasma protein corona on NP surface protects RBCs from both hydrophilic and hydrophobic NP-mediated hemolysis [48]. Against this backdrop, we believe that it would be interesting to examine the effects of various $\mathrm{TiO} 2 \mathrm{NPs}$ for thrombotic risk mediated by RBCs in the future.

\section{Conclusion}

Our study revealed the prothrombotic effect of $\mathrm{TiO}_{2}$ NPs via the procoagulant activity of RBCs, which we demonstrated with in vitro and in vivo assessments. We could also propose the mechanism underlying by 


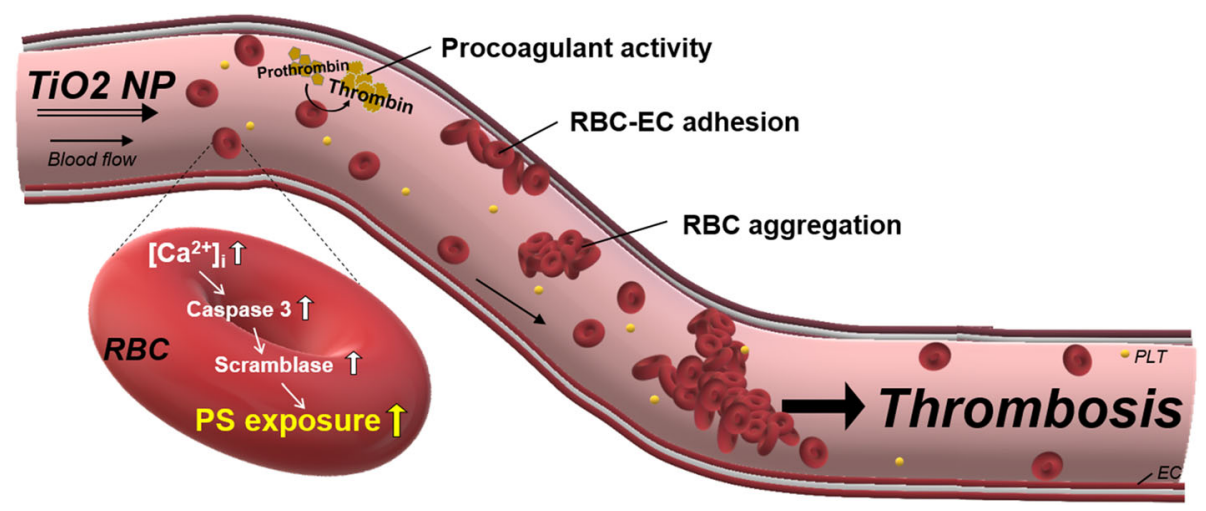

Scheme 1 Venous Thrombosis induced by $\mathrm{TiO}_{2}$ NPs via RBCs.

showing that $\mathrm{TiO}_{2}$ NPs-induced PS exposure in isolated human $\mathrm{RBCs}$ was related to increased $\left[\mathrm{Ca}^{2+}\right]_{\mathrm{i}}$ level and caspase 3 activity but independent of ROS generation. Most importantly, we demonstrated the in vivo relevance of our findings through showing that $\mathrm{TiO}_{2} \mathrm{NPs}$ exposure can increase thrombosis in rat venous thrombosis model in vivo, reflecting the need of an attention during medical use of $\mathrm{TiO}_{2}$ NPs.

\section{Methods \\ Materials}

The following chemicals were purchased from Sigma Chemical Co. (St. Louis, $\mathrm{MO}$ ): $\mathrm{TiO}_{2}$ (titanium dioxide, anatase, nanopowder, $<25 \mathrm{~nm}$ particle size, $99.7 \%$ trace metals basis.), L-ascorbic acid, $\mathrm{N}$-acetylcysteine, glutaldehyde solution and osmium tetroxide, $\mathrm{CaCl}_{2}$, glucose, ethylenediaminetetraacetic acid (EDTA), bovine serum albumin (BSA), $\mathrm{N}$-[2Hydroxyethyl]piperazine- $\mathrm{N}^{\prime}$-[2-ethanesulfonic acid] (HEPES), sodium dodecyl sulfate and purified human thrombin. Phycoerythrin-labeled monoclonal mouse anti-human CD235a and fluoresceinisothiocyanate (FITC)-labeled annexin V (annexin VFITC) were from BD Pharmingen (San Diego, CA). Fluo-4 acetoxymethyl ester (fluo-4 AM) and the chloromethyl derivative of 2', 7'-dichlorodihydrofluorescein diacetate $\left(\mathrm{CM}-\mathrm{H}_{2} \mathrm{DCF}-\mathrm{DA}\right)$ were obtained from Life Technologies. 1-Palmitoyl-2-[6-[(7-nitro-2-1,3-benzoxadiazol-4-yl)amino]hexanoyl]-snglycero-3-phospho-L-serine ( $\mathrm{C}_{6}$-NBD-PS) and 1-oleoyl-2-[6-[(7-nitro-2-1,3-benzoxadiazol-4-yl)amino]hexanoyl]-sn-glycero-3-phosphocholine ( $\mathrm{C}_{6}$-NBD-PC) were from Avanti Polar Lipids (Alabaster, AL). Caspase 3 detection kit (FITC-DEVE-FMK) was purchased from Calbiochem (San Diego, CA). Caspase-3 inhibitor II and Q-VD-OPh were obtained from Merck Millipore. Purified human prothrombin, factor Xa and factor Va were from Hematologic Technologies, Inc. (Essex Junction, VT), and S2238 was from Chromogenix (Milano, Italy). Human umbilical vein endothelial cells (HUVECs) and the endothelial cell growth media (EGM) kit were purchased from
Lonza. Calcein-green AM was from Invitrogen (Carlsbad, CA). Human recombinant tissue factor (Recombiplastin) was obtained from Instrumentation Laboratory (Lexington, MA) and thromboplastin (Simplastin Excel) was from Biomerieux (Durham, NC).

\section{Preparation of RBCs}

With the approval from the Ethics Committee of Health Service Center at Seoul National University, we collected blood from healthy volunteers. As gender, age and diseases are all risk factors of thrombosis, we only used healthy male donors ranging from 20 to 30 years old to simplify our study design. Human blood was collected using a vacutainer with acid citrate dextrose $(A C D)$ and a 21 gauge needle (Becton Dickinson, U.S.A.) on the day of each experiments. Platelet rich plasma and buffy coat were removed after centrifugation at $200 \mathrm{~g}$ for $15 \mathrm{~min}$. Packed RBCs were washed twice with phosphate buffered saline (PBS: $1.06 \mathrm{mM} \mathrm{KH}_{2} \mathrm{PO}_{4}, 154 \mathrm{mM} \mathrm{NaCl}$ and $2.96 \mathrm{mM} \mathrm{Na}_{2} \mathrm{HPO}_{4}$ at $\mathrm{pH}$ 7.4) and once with Ringer's solution (125 mM NaCl, $5 \mathrm{mM} \mathrm{KCl,} 1 \mathrm{mM} \mathrm{MgSO}$, $32 \mathrm{mM}$ HEPES, $5 \mathrm{mM}$ glucose, $\mathrm{pH}$ 7.4). Washed RBCs were resuspended in Ringer's solution to a final cell concentration of $5 \times 10^{7}$ cells $/ \mathrm{mL}$ with $1 \mathrm{mM} \mathrm{CaCl}{ }_{2}$ before use.

\section{Characterization of $\mathrm{TiO}_{2} \mathrm{NPs}$}

$\mathrm{TiO}_{2}$ NPs were purchased from Sigma Aldrich (reference 637,254 ). They are nano powder, $<25 \mathrm{~nm}$ particle size and $99.7 \%$ trace metals basis. All heavy metal impurities detected in the sample were equal to/under 65 $\mathrm{ppm}$ via XRF. The density is $3.9 \mathrm{~g} / \mathrm{ml}$ (relative density) and $0.04-0.06 \mathrm{~g} / \mathrm{mL}$ (bulk density). Fusion temperature was determined as $1825^{\circ} \mathrm{C}$ and specific surface area as $44-55 \mathrm{~m}^{2} / \mathrm{g}$ via BET. It is not surface treated. Sigma did not test the solubility or dissolution of this product. However, these products are insoluble in water, $\mathrm{HCl}$, $\mathrm{HNO}_{3}$ and dilute $\mathrm{H}_{2} \mathrm{SO}_{4}$. It is soluble in hot concentrated $\mathrm{H}_{2} \mathrm{SO}_{4}$ and hydrofluoric acid (supplier data). Preparation of $\mathrm{TiO}_{2}$ NPs suspension was carried out 
according to the methods previously described. $\mathrm{TiO}_{2}$ NPs were dispersed in distilled water as $100 \mathrm{X}$ stock solution $(1-25 \mathrm{mg} / \mathrm{mL})$ and sonicated with a probe type sonicator with a maximum output power, $200 \mathrm{~W}$ (Branson Sonifier, Danbury, CT) for $30 \mathrm{~s}$ to prevent particles self-assembly (agglomeration) prior to each experiment. For the characterization of $\mathrm{TiO}_{2} \mathrm{NPs}, \mathrm{TiO}_{2} \mathrm{NPs}$ was dried and was observed with scanning electron microscope (SEM) (ZEISS, MERLIN Compact) to examine the size distribution. A detailed statistical analysis of $\mathrm{TiO}_{2}$ NPs was performed by randomly measuring 100 nanoparticles and the procedure was operated by manually outlining the particles from several images taken by SEM. The hydrodynamic diameter and the zeta potential of the nanoparticles were measured by dynamic light scattering (DLS-7000, Otsuka Electronics, Co., Osaka, Japan) and electrophoretic light scattering (ELSZ-1000 Photal; Otsuka Electronics,Co., Osaka, Japan), respectively.

Cellular uptake of $\mathrm{TiO}_{2}$ NPs by RBCs was observed using TEM after the following procedures. After $24 \mathrm{~h}$ incubation of isolated RBCs with distilled water (as control) and $25 \mu \mathrm{g} / \mathrm{mL}$ of $\mathrm{TiO}_{2}$ NPs dispersed as a colloidal suspension in distilled water, $2 \%$ glutaraldehyde solution was used for cell fixation in the refrigerator for $1 \mathrm{~h}$ and $1 \%$ osmium tetroxide was used for post-fixation for $2 \mathrm{~h}$. After en-bloc staining with $0.5 \%$ uranyl acetate for 30 min, serially dehydration was done with $30,50,70,80$, 90\% (1 time) and 100\% ethanol (3 times). Next, transition and infiltration was gradually done with propylene oxide (10 min, 2 times), once with propylene oxide and spurr's resin $(1,1)$ for $2 \mathrm{~h}$, and spurr's resin in the desiccator overnight. On the next day, infiltration was completed with newly spurr's resin for $2 \mathrm{~h}$ in the desiccator, then samples were kept in the $70^{\circ} \mathrm{C}$ oven overnight for polymerization. Finally, samples were observed under TEM (JEOL, JEM 1010).

\section{Evaluation of hemolysis}

After incubation with $\mathrm{TiO}_{2}$ NPs, samples were centrifuged (10,000 g for $1 \mathrm{~min}$ ) and the extent of hemolysis was determined spectrophotometrically at $540 \mathrm{~nm}$. Ringer's solution and RBCs lysed with triton X-100 were used as blank and $100 \%$ hemolysis, respectively.

\section{Flow cytometric analysis}

Annexin V-FITC and anti-glycophorin A-PE were used for PS detection and RBC identification, respectively. Negative controls for annexin $\mathrm{V}$ binding were in the presence of $2.5 \mathrm{mM}$ EDTA instead of $2.5 \mathrm{mM} \mathrm{CaCl}$. Flow cytometer FACS Calibur (Becton Dickinson, U.S.A.) equipped with an argon-ion laser emitting at $488 \mathrm{~nm}$ was applied for sample analysis. Data from 5000 events were collected and analyzed using Cell Quest Pro software. PS were identified by forward scatter characteristics after calibration by $1 \%$ standard beads. Both PS exposure in RBC area and MV area could be analyzed.

For determination of phospholipid translocation, $0.5 \mu \mathrm{M} \mathrm{C}_{6}$-NBD-PC (for scramblase activity) and $\mathrm{C}_{6}$ NBD-PS (for flippase activity) were added to $\mathrm{TiO}_{2}$ NPsactivated RBCs, respectively, for various durations $(0,20$, 40 and $60 \mathrm{~min}$ ) at $37^{\circ} \mathrm{C}$. The amount of internalized probe was determined by comparing the fluorescence intensity associated with the cells before (without $1 \%$ bovine serum albumin) and after (with $1 \%$ bovine serum albumin) back-extraction on ice for $10 \mathrm{~min}$.

With flow cytometry, ROS generation and intracellular calcium $\left(\left[\mathrm{Ca}^{2+}\right]_{\mathrm{i}}\right)$ were performed by determination of the fluorescence of intracellular DCF with pre-loading $5 \mu \mathrm{M}$ CM- $\mathrm{H}_{2}$ DCF-DA with RBCs $\left(30 \mathrm{~min}, 60 \mathrm{rpm}, 37^{\circ} \mathrm{C}\right.$ water bath, dark) and the fluorescence of fluo- 4 with pre-loading $3 \mu \mathrm{M}$ Fluo- $4 \mathrm{AM}$ with RBCs $(1 \mathrm{~h}, 60 \mathrm{rpm}$, $37^{\circ} \mathrm{C}$ water bath, dark) before $\mathrm{TiO}_{2} \mathrm{NPs}$ treatments.

As well, caspase- 3 activity was measured by postadding $1 \mu \mathrm{L}$ FITC-DEVD-FMK (a caspase-3 inhibitor conjugated to FITC as the fluorescent in situ marker) to $300 \mu \mathrm{L} \quad \mathrm{TiO}_{2}$ NPs exposed-RBCs suspension $\left(37^{\circ} \mathrm{C}\right.$, $1000 \mathrm{rpm}$, dark). Re-suspended cells after centrifugation (1000 $\mathrm{g}$ for $5 \mathrm{~min}$ ) and twice washing was detected using flow cytometry. Data from 5000 events were collected and analyzed using Cell Quest Pro software (Becton Dickinson).

\section{Morphological alteration observation using scanning electron microscopy (SEM)}

After incubation with $\mathrm{TiO}_{2}$ NPs, RBCs were pre-fixed with $2 \%$ glutaraldehyde solution for $1 \mathrm{~h}$ at $4{ }^{\circ} \mathrm{C}$ and postfixed with $1 \%$ osmium tetroxide for $30 \mathrm{~min}$ at room temperature in the hood. Then, samples were dehydrated serially with 50, 70, 80, 90, and $100 \%$ ethanol. After drying and coating with gold, the morphological alteration were observed on a SEM.

\section{Experiments with plasma}

Platelet-poor plasma (PPP) was obtained from the precipitated fraction of PRP by centrifugation for $20 \mathrm{~min}$ at 2000 g. In PPP, PT and aPTT were measured in BBL Fibrometer (Becton Dickinson, Cockeysville, Maryland), based upon the procedures in PT and aPTT reagent kit, respectively.

\section{Prothrombinase assay}

After incubation with $\mathrm{TiO}_{2} \mathrm{NPs}$ for $24 \mathrm{~h}$, samples were incubated with $5 \mathrm{nM}$ factor $\mathrm{Xa}$ and $10 \mathrm{nM}$ factor $\mathrm{Va}$ in Tyrode buffer (134 mM NaCl, $10 \mathrm{mM}$ HEPES, $5 \mathrm{mM}$ glucose, $2.9 \mathrm{mM} \mathrm{KCl}, 1 \mathrm{mM} \mathrm{MgCl}, 12 \mathrm{mM} \mathrm{NaHCO}$, $0.34 \mathrm{mM} \mathrm{Na}_{2} \mathrm{HPO}_{4}, 0.3 \% \mathrm{BSA}$, and $2 \mathrm{mM} \mathrm{CaCl}_{2}$ at $\mathrm{pH}$ 7.4) for $3 \mathrm{~min}$ at $37^{\circ} \mathrm{C}$. Thrombin formation was 
initiated by adding $2 \mu \mathrm{M}$ prothrombin. Exactly $3 \mathrm{~min}$ after adding prothrombin, an aliquot of the suspension was transferred to a tube containing stop buffer $(50 \mathrm{mM}$ Tris- $\mathrm{HCl}, 120 \mathrm{mM} \mathrm{NaCl}$, and $2 \mathrm{mM}$ EDTA at $\mathrm{pH} 7.9)$. Thrombin activity was determined using the chromogenic substrate S2238 (chromogenic substrate for thrombin; Chromogenix, Milano, Italy). We calculated the rate of thrombin generation from the change in absorbance at $405 \mathrm{~nm}$ using a calibration curve generated with active-site-titrated thrombin.

\section{Observation under fluorescence microscope}

Endothelial cells $\left(2 \times 10^{4}\right.$ cells $)$ were seeded in a 4-wellchamber for 2 days and stained with calcein green for 20 min. $\mathrm{TiO}_{2}$ NPs-treated RBCs were washed once and resuspended in EBM-2 to a final cell concentration of $5 \times 10^{7}$ cells $/ \mathrm{mL}$. After HUVECs were washed twice with EBM-2, $\mathrm{TiO}_{2}$ NPs-exposed RBCs were layered onto confluent HUVEC monolayer and incubated for $60 \mathrm{~min}$ at $37^{\circ} \mathrm{C}$. After the incubation, the chambers were rinsed once with EBM-2 to remove non-adherent RBCs, and glycophorin A-PE were added for staining RBCs. Adhered RBCs to HUVECs were observed using fluorescent microscopy.

Moreover, aggregation of chemical-exposed RBCs was observed using fluorescence microscopy after adding glycophorin A-PE.

\section{In vivo assessment}

Sprgue-Dawley (SD) rats (male, 300-400 g) were anesthetized with urethane $(1.25 \mathrm{~g} / \mathrm{kg}$, i.p.). Blood (3.8\% sodium citrate) was collected from abdominal aorta and $\mathrm{RBCs}$ were isolated as human RBCs preparation. Isolated rat RBCs were further incubated with $\mathrm{TiO}_{2} \mathrm{NPs}$ for $24 \mathrm{~h}$, then PS exposure and procoagulant activity were determined mentioned above.

In a thrombosis animal model, we surgically opened the abdomen and carefully dissected to expose the vena cava. A $16 \mathrm{~mm}$ apart around the vena cava was prepared with two pieces of loose cotton threads each side and we ligated all side branches tightly with cotton threads. Here, the NPs were suspended in saline $(0.9 \% \mathrm{NaCl})$ for intravenous injection. $1 \mathrm{~h}$ after intravenously injecting $\mathrm{TiO}_{2}$ NPs $(0,2,10$ or $25 \mathrm{mg} / \mathrm{kg})$ into a left femoral vein, we infused 500-fold diluted thromboplastin for $1 \mathrm{~min}$ to induce thrombus formation. Stasis was initiated by tightening the two threads, first the proximal and the distal thereafter. The abdominal cavity was provisionally closed, and blood stasis was maintained for $15 \mathrm{~min}$. After reopening the abdomen, the ligated venous segment was excised and opened longitudinally to remove the thrombus. The isolated thrombus was blotted of excess blood and immediately weighed.

\section{Statistical analysis}

The means and standard errors of means were calculated for all treatment groups. The data were subjected to two-way analysis of variance followed by Duncan's multiple range test or student $\mathrm{t}$ test to determine which means were significantly different from the control. In all cases, a $p$ value of $<.05$ was used to determine significant differences.

\section{Supplementary Information}

The online version contains supplementary material available at https://doi. org/10.1186/s12989-021-00422-1.

Additional file $\mathbf{1}$ Table S1. Summary of physicochemical properties of $\mathrm{TiO}_{2}$ NPS.

Additional file 2 Figure S1. Comparison of anatase, rutile and anatase/rutile mixture $\mathrm{TiO}_{2} \mathrm{NPs}$ on hemoytic response and PS exposure in human isolated RBCs. (a) Hemolysis and (b) PS exposure of human isolated red blood cells was determined after $24 \mathrm{~h}$ exposure to $50 \mu \mathrm{g} / \mathrm{mL}$ of each types of TiO2 NPs including anatase, rutile (Sigma 637,262, nanopowder, < $100 \mathrm{~nm}$ particle size via BET, $99.5 \%$ trace metals basis) and anatase/rutile mixture (Sigma 634,662, < $100 \mathrm{~nm}$ particle size via BET, $99.5 \%$ trace metals basis). Values are mean \pm S.E. of $3-5$ independent experiments, ${ }^{*}$ represents significant differences from the control group $(p<0.05)$.

\section{Acknowledgements}

Not applicable.

\section{Authors' contributions}

Y. B. designed and performed the experiments; H.Y.C. did a part of animal experiments. O.N.B. and K.M.L.analyzed the data; J. P. and J.H.C. supervised the study.

\section{Funding}

This research was supported by the National Research Foundation of Korea (NRF) grant funded by the Korea Government (MSIP)

(2015R1A2A2A01011705), National Natural Science Foundation of China (No. 82020108027 and No.82003500) as well as the Talent Introduction Program of Postdoctoral International Exchange Program (No. YJ20190263).

\section{Availability of data and materials \\ Yes}

\section{Declarations}

Ethics approval

With the approval from the Ethics Committee of Health Service Center at Seoul National University and China Medical University, human blood was obtained from healthy male donors. All the animal protocols used in vivo experiments were approved by the Ethics Committee of Animal Service Center at Seoul National University.

\section{Consent for publication}

Not applicable.

\section{Competing interests \\ None declared.}

\section{Author details}

${ }^{1}$ School of Public Health, China Medical University, Shenyang 110122, People's Republic of China. ${ }^{2}$ Department of Agricultural Biotechnology, and Center for Food Safety and Toxicology, Seoul National University, Seoul 151-742, South Korea. ${ }^{3}$ College of Pharmacy, Hanyang University, Ansan, Gyeonggido 426-791, South Korea. ${ }^{4}$ College of Pharmacy, Ewha Womans University, Seoul 120-750, South Korea. ${ }^{5}$ College of Pharmacy, Seoul National University, Seoul 151-742, South Korea. 


\section{Received: 19 October 2019 Accepted: 21 July 2021}

\section{Published online: 04 August 2021}

\section{References}

1. Hou Z, Zhang Y, Deng K, Chen Y, Li X, Deng X, et al. UV-emitting upconversion-based $\mathrm{TiO} 2$ photosensitizing nanoplatform: near-infrared light mediated in vivo photodynamic therapy via mitochondria-involved apoptosis pathway. ACS Nano. 2015;9(3):2584-99. https://doi.org/10.1021/ nn506107c.

2. Yin ZF, et al. Recent progress in biomedical applications of titanium dioxide. Phys Chem Chem Phys. 2013;15(14):4844-58. https://doi.org/10.1039/c3cp43 $938 \mathrm{k}$

3. Qin Y, Sun L, Li X, Cao Q, Wang H, Tang $X$, et al. Highly water-dispersible TiO 2 nanoparticles for doxorubicin delivery: effect of loading mode on therapeutic efficacy. J Mater Chem. 2011;21(44):18003-10. https://doi.org/1 0.1039/c1jm13615a.

4. Dimitrijevic NM, Rozhkova E, Rajh T. Dynamics of localized charges in dopamine-modified $\mathrm{TiO} 2$ and their effect on the formation of reactive oxygen species. J Am Chem Soc. 2009;131(8):2893-9. https://doi.org/10.1 021/ja807654k.

5. Paunesku T, Vogt S, Lai B, Maser J, Stojićević N, Thurn KT, et al. Intracellular distribution of TiO2- DNA oligonucleotide nanoconjugates directed to nucleolus and mitochondria indicates sequence specificity. Nano Lett. 2007; 7(3):596-601. https://doi.org/10.1021/nl0624723.

6. Shi H, Magaye R, Castranova V, Zhao J. Titanium dioxide nanoparticles: a review of current toxicological data. Part Fibre Toxicol. 2013;10(1):15. https:// doi.org/10.1186/1743-8977-10-15.

7. Ghosh M, Chakraborty A, Mukherjee A. Cytotoxic, genotoxic and the hemolytic effect of titanium dioxide (TiO2) nanoparticles on human erythrocyte and lymphocyte cells in vitro. J Appl Toxicol. 2013;33(10):1097110. https://doi.org/10.1002/jat.2863.

8. Gaharwar US, Meena R, Rajamani P. Iron oxide nanoparticles induced cytotoxicity, oxidative stress and DNA damage in lymphocytes. J Appl Toxicol. 2017;37(10):1232-44. https://doi.org/10.1002/jat.3485.

9. Jun E-A, Lim KM, Kim KY, Bae ON, Noh JY, Chung KH, et al. Silver nanoparticles enhance thrombus formation through increased platelet aggregation and procoagulant activity. Nanotoxicology. 2011;5(2):157-67. https://doi.org/10.3109/17435390.2010.506250.

10. Fröhlich $\mathrm{E}$. Action of nanoparticles on platelet activation and plasmatic coagulation. Curr Med Chem. 2016;23(5):408-30. https://doi.org/10.2174/092 9867323666160106151428 .

11. Zhao Y, Sun X, Zhang G, Trewyn BG, Slowing II, Lin VSY. Interaction of mesoporous silica nanoparticles with human red blood cell membranes: size and surface effects. ACS Nano. 2011;5(2):1366-75. https://doi.org/10.1 021/nn103077k.

12. Avsievich T, Popov A, Bykov A, Meglinski I. Mutual interaction of red blood cells influenced by nanoparticles. Sci Rep. 2019;9(1):5147. https://doi.org/10.1 038/s41598-019-41643-x.

13. Chen LQ, Fang L, Ling J, Ding CZ, Kang B, Huang CZ. Nanotoxicity of silver nanoparticles to red blood cells: size dependent adsorption, uptake, and hemolytic activity. Chem Res Toxicol. 2015;28(3):501-9. https://doi.org/10.1 021/tx500479m.

14. Shin J-H, Lim KM, Noh JY, Bae ON, Chung SM, Lee MY, et al. Lead-induced procoagulant activation of erythrocytes through phosphatidylserine exposure may lead to thrombotic diseases. Chem Res Toxicol. 2007;20(1): 38-43. https://doi.org/10.1021/tx060114+.

15. Daleke DL. Regulation of phospholipid asymmetry in the erythrocyte membrane. Curr Opin Hematol. 2008;15(3):191-5. https://doi.org/10.1097/ $\mathrm{MOH} .0 \mathrm{~b} 013 \mathrm{e} 3282 \mathrm{fg}$ af7.

16. Pomorski T, Menon A. Lipid flippases and their biological functions. Cell Mol Life Sci. 2006;63(24):2908-21. https://doi.org/10.1007/s00018-006-6167-7.

17. Suzuki J, Fujii T, Imao T, Ishihara K, Kuba H, Nagata S. Calcium-dependent phospholipid scramblase activity of TMEM16 protein family members. J Biol Chem. 2013;288(19):13305-16. https://doi.org/10.1074/jbc.M113.457937.

18. Daleke DL. Regulation of transbilayer plasma membrane phospholipid asymmetry. J Lipid Res. 2003;44(2):233-42. https://doi.org/10.1194/Jr.R200019-JLR200.

19. Hankins HM, Baldridge RD, Xu P, Graham TR. Role of flippases, scramblases and transfer proteins in phosphatidylserine subcellular distribution. Traffic. 2015;16(1):35-47. https://doi.org/10.1111/tra.12233.

20. Tiwari BS, Belenghi B, Levine A. Oxidative stress increased respiration and generation of reactive oxygen species, resulting in ATP depletion, opening of mitochondrial permeability transition, and programmed cell death. Plant Physiol. 2002;128(4):1271-81. https://doi.org/10.1104/pp.010999.

21. Banerjee T, Kuypers FA. Reactive oxygen species and phosphatidylserine externalization in murine sickle red cells. Br J Haematol. 2004;124(3):391402. https://doi.org/10.1046/j.1365-2141.2003.04781.x.

22. Bian Y, Kim K, Ngo T, Kim I, Bae ON, Lim KM, et al. Silver nanoparticles promote procoagulant activity of red blood cells: a potential risk of thrombosis in susceptible population. Part Fibre Toxicol. 2019;16(1):9. https://doi.org/10.1186/s12989-019-0292-6.

23. Rothen-Rutishauser BM, Schürch S, Haenni B, Kapp N, Gehr P. Interaction of fine particles and nanoparticles with red blood cells visualized with advanced microscopic techniques. Environ Sci Technol. 2006;40(14):4353-9. https://doi.org/10.1021/es0522635.

24. Li S-Q, Zhu RR, Zhu H, Xue M, Sun XY, Yao SD, et al. Nanotoxicity of TiO2 nanoparticles to erythrocyte in vitro. Food Chem Toxicol. 2008;46(12):362631. https://doi.org/10.1016/j.fct.2008.09.012.

25. Lim K-M, Kim S, Noh JY, Kim K, Jang WH, Bae ON, et al. Low-level mercury can enhance procoagulant activity of erythrocytes: a new contributing factor for mercury-related thrombotic disease. Environ Health Perspect. 2010;118(7):928-35. https://doi.org/10.1289/ehp.0901473.

26. Fadok VA, de Cathelineau A, Daleke DL, Henson PM, Bratton DL. Loss of phospholipid asymmetry and surface exposure of phosphatidylserine is required for phagocytosis of apoptotic cells by macrophages and fibroblasts. J Biol Chem. 2001;276(2):1071-7. https://doi.org/10.1074/jbc. M003649200.

27. Yang H, Kim A, David T, Palmer D, Jin T, Tien J, et al. TMEM16F forms a Ca2+-activated cation channel required for lipid scrambling in platelets during blood coagulation. Cell. 2012;151(1):111-22. https://doi.org/10.1016/j. cell.2012.07.036.

28. Görlach A, Bertram K, Hudecova S, Krizanova O. Calcium and ROS: a mutual interplay. Redox Biol. 2015;6:260-71. https://doi.org/10.1016/j.redox.2015.08.010.

29. DeJong K, et al. High Calcium Requirement for Phosphatidylserine Exposure in Sickle Cell Disease. Blood. 2006;108(11):3788.

30. Mariño G, Kroemer G. Mechanisms of apoptotic phosphatidylserine exposure. Cell Res. 2013;23(11):1247-8. https://doi.org/10.1038/cr.2013.115.

31. Kim K, Bae ON, Koh SH, Kang S, Lim KM, Noh JY, et al. High-dose vitamin C injection to cancer patients may promote thrombosis through procoagulant activation of erythrocytes. Toxicol Sci. 2015;147(2):350-9. https://doi.org/10.1 093/toxsci/kfv133.

32. Diehl $K$, Hull $R$, Morton D, Pfi ster R, Rabemampianina $Y$, Smith $D$, et al. A good practice guide to the administration of substances and removal of blood, including routes and volumes. J Appl Toxicol. 2001;21(1):15-23. https://doi.org/10.1002/jat.727.

33. Meena R, Paulraj R. Oxidative stress mediated cytotoxicity of $\mathrm{TiO} 2$ nano anatase in liver and kidney of Wistar rat. Toxicol Environ Chem. 2012;94(1): 146-63. https://doi.org/10.1080/02772248.2011.638441.

34. Laomettachit T, Puri I, Liangruksa M. A two-step model of TiO2 nanoparticle toxicity in human liver tissue. Toxicol Appl Pharmacol. 2017;334:47-54. https://doi.org/10.1016/j.taap.2017.08.018.

35. Aisaka Y, Kawaguchi R, Watanabe S, Ikeda M, Igisu H. Hemolysis caused by titanium dioxide particles. Inhal Toxicol. 2008;20(9):891-3. https://doi.org/1 0.1080/08958370802304123.

36. Shakeel M, Jabeen F, Shabbir S, Asghar MS, Khan MS, Chaudhry AS. Toxicity of nano-titanium dioxide (TiO 2-NP) through various routes of exposure: a review. Biol Trace Elem Res. 2016;172(1):1-36. https://doi.org/10.1007/s12 011-015-0550-x.

37. Xu J, Shi H, Ruth M, Yu H, Lazar L, Zou B, et al. Acute toxicity of intravenously administered titanium dioxide nanoparticles in mice. PLoS One. 2013;8(8):e70618. https://doi.org/10.1371/journal.pone.0070618.

38. Fabian E, Landsiedel R, Ma-Hock L, Wiench K, Wohlleben W, van Ravenzwaay $B$. Tissue distribution and toxicity of intravenously administered titanium dioxide nanoparticles in rats. Arch Toxicol. 2008;82(3):151-7. https://doi.org/10.1007/s00204-007-0253-y.

39. Elgrabli D, Beaudouin $\mathrm{R}$, Jbilou N, Floriani M, Pery A, Rogerieux F, et al. Biodistribution and clearance of $\mathrm{TiO} 2$ nanoparticles in rats after intravenous injection. PLoS One. 2015;10(4):e0124490. https://doi.org/10.1371/journal. pone.0124490.

40. Geraets L, Oomen AG, Krystek $P$, Jacobsen NR, Wallin H, Laurentie M, et al. Tissue distribution and elimination after oral and intravenous administration of different titanium dioxide nanoparticles in rats. Part Fibre Toxicol. 2014; 11(1):30. https://doi.org/10.1186/1743-8977-11-30. 
41. Xiong D, Fang T, Yu L, Sima X, Zhu W. Effects of nano-scale TiO2, ZnO and their bulk counterparts on zebrafish: acute toxicity, oxidative stress and oxidative damage. Sci Total Environ. 2011;409(8):1444-52. https://doi.org/1 0.1016/j.scitotenv.2011.01.015

42. Liu H, Ma L, Liu J, Zhao J, Yan J, Hong F. Toxicity of nano-anatase TiO2 to mice: liver injury, oxidative stress. Toxicol Environ Chem. 2010;92(1):175-86. https://doi.org/10.1080/02772240902732530.

43. Relier C, Dubreuil M, Lozano Garcì O, Cordelli E, Mejia J, Eleuteri P, et al. Study of TiO2 P25 nanoparticles genotoxicity on lung, blood, and liver cells in lung overload and non-overload conditions after repeated respiratory exposure in rats. Toxicol Sci. 2017;156(2):527-37. https://doi.org/10.1093/ toxsci/kfx006.

44. De Matteis $\mathrm{V}$, et al. Toxicity assessment of anatase and rutile titanium dioxide nanoparticles: the role of degradation in different $\mathrm{pH}$ conditions and light exposure. Toxicol in Vitro. 2016;37:201-10. https://doi.org/10.1016/ j.tiv.2016.09.010.

45. Han Y, Wang X, Dai H, Li S. Nanosize and surface charge effects of hydroxyapatite nanoparticles on red blood cell suspensions. ACS Appl Mater Interfaces. 2012;4(9):4616-22. https://doi.org/10.1021/am300992x.

46. Purohit R, Vallabani NVS, Shukla RK, Kumar A, Singh S. Effect of gold nanoparticle size and surface coating on human red blood cells. Bioinspired Biomimetic Nanobiomaterials. 2016;5(3):121-31. https://doi.org/10.1680/ jbibn.15.00018.

47. Gunawan C, Lim M, Marquis CP, Amal R. Nanoparticle-protein corona complexes govern the biological fates and functions of nanoparticles. J Mater Chem B. 2014;2(15):2060-83. https://doi.org/10.1039/c3tb21526a.

48. Saha K, Moyano DF, Rotello VM. Protein coronas suppress the hemolytic activity of hydrophilic and hydrophobic nanoparticles. Materials Horizons. 2014;1(1):102-5. https://doi.org/10.1039/C3MH00075C.

\section{Publisher's Note}

Springer Nature remains neutral with regard to jurisdictional claims in published maps and institutional affiliations.

Ready to submit your research? Choose BMC and benefit from:

- fast, convenient online submission

- thorough peer review by experienced researchers in your field

- rapid publication on acceptance

- support for research data, including large and complex data types

- gold Open Access which fosters wider collaboration and increased citations

- maximum visibility for your research: over $100 \mathrm{M}$ website views per year

At $\mathrm{BMC}$, research is always in progress.

Learn more biomedcentral.com/submissions 